\title{
A Tribute to Professor Gary Bouma, MDiv, MA, PhD, AM (1942-2021)
}

\author{
Marion Maddox \\ Macquarie University \\ Macquarie Park, NSW 2109 \\ Australia \\ marion.maddox@mq.edu.au
}

\author{
Anna Halafoff \\ Deakin University \\ Waurn Ponds, Victoria 3216 \\ Australia \\ anna.halafoff@deakin.edu.au
}

\author{
Kathleen McPhillips \\ University of Newcastle \\ Callaghan, NSW 2308 \\ Australia \\ kathleen.mcphillips@newcastle.edu.au
}

Members of the Australian Association for the Study of Religion (AASR) are mourning our friend, mentor and colleague, Gary Bouma, who died unexpectedly on 19 August 2021.

Gary's massive academic legacy includes over 30 books and 360 articles-with many still forthcoming. His most recent book, authored with Andrew Singleton, Anna Halafoff and Mary Lou Rasmussen, Freedoms, Faiths and Futures: Teenage Australians on Religion, Sexuality and Diversity, arising from an ARC Discovery Project, was published in April this year (Singleton et al. 2021). As well as landmark works on the sociology of Australian religion, including Australian Soul (Bouma 2006), he reshaped Australian understanding of religion in numerous areas including interreligious understanding, human rights, religion and youth, education and public policy. His work reached far beyond the academy, with notable policy work including the Human Rights Commission's 2011 inquiry into Freedom of Religion and Belief in 21st 
Century Australia; chairing the Board of Directors for the Parliament of the World's Religions in 2009; and numerous interventions in public debate in areas such as religious diversity, gender and sexuality, Islamophobia and the place of religion in schools.

AASR members and JASR readers often saw Gary's thought in these areas unfolding, such as his 2013 AASR Presidential Address 'Religion and Sex: Marriage Equality and the Attempt to Regulate Intimacy in a Multifaith Society' (Bouma 2014) and his 2015 Charles Strong lecture 'Two Disconnected Discourses of Disconnection: Anti-West and AntiIslamic Discourses' (Bouma 2016). As well as ideas, he generously gave the AASR his boundless support for younger scholars, and perennial enthusiasm to make new discoveries and engage with new perspectives.

Gary came to Australia in 1979, joining Monash University, where he remained for the next 42 years, becoming Emeritus Professor in 2008, after serving in numerous roles including Professor of Sociology, Deputy Vice-Chancellor (Research), and Head of School. In 2005, he was appointed UNESCO Chair in Inter-Cultural and Inter-Religious Relations. He led the Australian node of the University of Ottawa-based Religion and Diversity Project and was a leading figure in other distinguished national and international research collaborations. In 2013, he was made a Member of the Order of Australia (AM) for services to sociology, to interreligious relations and to the Anglican Church of Australia.

Alongside his towering profile in the sociology of religion, Gary was an ordained minister in the Anglican church, and at the time of his death was Honorary Assistant Priest at St Johns, East Malvern.

Gary was a past President and an active supporter and contributor to the AASR through the journal and conferences, and a number of AASR members were very close colleagues and friends. He will be deeply missed and warmly remembered.

\section{References}

Bouma, Gary

2006 Australian Soul: Religion and Spirituality in the 21st Century. Cambridge University Press, Port Melbourne.

2014 Religion and Sex: Marriage Equality and the Attempt to Regulate Intimacy in a Multifaith Society. Journal for the Academic Study of Religion 27(1): 3-19. https://doi.org/10.1558/jasr.v27i1.3

2016 Two Disconnected Discourses of Disconnection: Anti-West and AntiIslamic Discourses. Journal for the Academic Study of Religion 29(1):

3-12. https://doi.org/10.1558/jasr.v29i1.30375

Singleton, Andrew, Anna Halafoff, Mary Lou Rasmussen and Gary Bouma

2021 Freedoms, Faiths and Futures: Teenage Australians on Religion, Sexuality and Diversity. Bloomsbury Academic, London. 